\title{
NEW RECORD OF MOTHER-CALF PAIR OF SOUTHERN RIGHT WHALE, EUBALAENA AUSTRALIS, OFF THE PERUVIAN COAST
}

\author{
Luis Santillán ${ }^{1,2}$, Milena Roca ${ }^{3}$, Manuel Apaza ${ }^{4}$, Larissa Rosa de Oliveira ${ }^{5}$, Karina Ontón ${ }^{1,6}$
}

On 26 August 2003 a new record of southern right whale Eubalaena australis was obtained for the Peruvian coast, off San Fernando Bay $\left(15^{\circ} 08^{\prime} \mathrm{S}, 75^{\circ} 21^{\prime} \mathrm{W}\right), 25 \mathrm{~km}$ north of San Juan de Marcona, Department of Ica (Figure 1). It represents a third confirmed sighting of E. australis for Peru after one sighting in November 1987 and another in September 1996 (Van Waerebeek et al., 1992; 1998). Based on behavioral cues and relative body sizes, the whales were a mother-calf pair. The mother measured an estimated $15 \mathrm{~m}$ in length and the calf was less than half the length of the adult. This sighting, by naked eye from shore, some $100 \mathrm{~m}$ away from the individuals from 14:00 until 14:30 hrs is the second case of a mother-calf pair of southern right whales documented in Peruvian waters. The other previous record in September 1996 was made by Van Waerebeek et al. (1998). The sighting documented in this note is the northernmost confirmed record of this species in the Southeast Pacific ocean. The whales in San Fernando Bay were sighted in a shallow water zone locally known as pasadizo. Most sightings of southern right whale with calves, registered on the Chilean coast were in shallow waters, with depths ranging from 5-30 meters (Aguayo et al., 1992). San Fernando Bay is generally quiet, and visited only by shellfish fishermen because it is difficult to reach, in spite of its relative proximity to San Juan de Marcona Port.

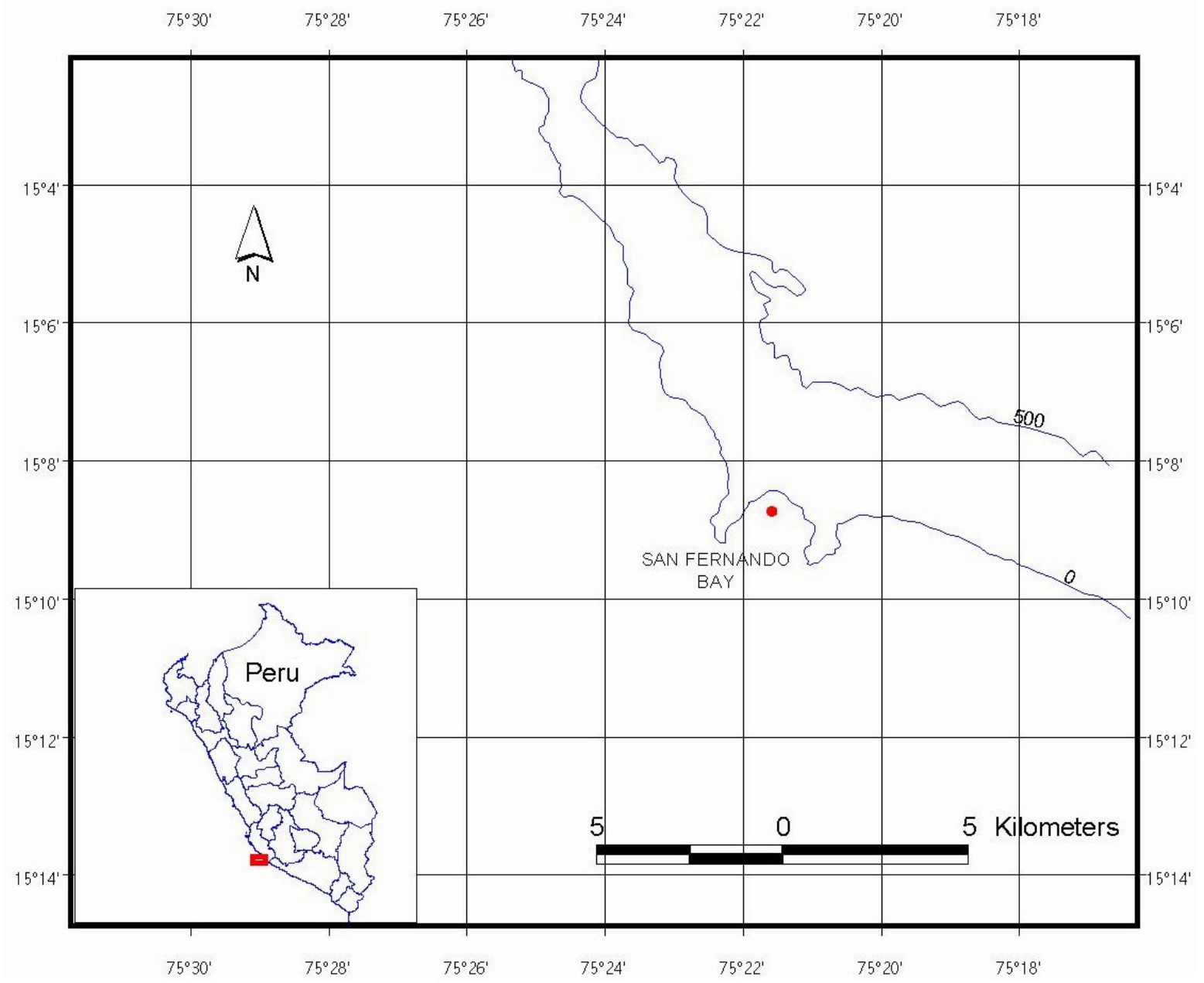

Figure 1. Sighting area of southern right whales.

\footnotetext{
${ }^{1}$ Centro Peruano de Estudios Cetológicos (CEPEC), Museo de los Delfines, Pucusana, Perú.

${ }^{2}$ Isantillancorrales@yahoo.com

${ }^{3}$ Proyecto Punta San Juan. milenaroca@hotmail.com

${ }^{4}$ Domingo de la Presa 140, Lima 33, Perú. mal@lamolina.edu.pe

${ }^{5}$ Grupo de Estudos de Mamíferos Aquáticos do Rio Grande do Sul (GEMARS) / CECLIMAR, Universidade Federal do Rio Grande do Sul. Brasil. lari@ib.usp.br
}

${ }^{6}$ karinaonton@hotmail.com 
The whales were near the surface at all times, maintaining the same position without moving any significant distance, with slow movements, and were observed for at least 30 minutes next to each other. Periodically the calf was seen to position itself opposite or at a right angle to the mother, presumably in attempts to suckle. During our observation period the mother did not seem to respond to this action. The back and head of the adult whale frequently became visible. Roughly $80-100 \mathrm{~m}$ from the whales, artisanal fishermen were diving and gathering shellfish from a small boat. Although the fishermen did not pay attention to the whales and hence did not actively harass them, their presence and activity appeared to disturb the whales. Shell fishermen of San Juan de Marcona informed that a large right whale had arrived alone at San Fernando Bay in early July (S.Quispe and P.Llerena, pers. comm.). Assuming this was the same adult, it is probable that parturition occurred in July or August. In the second half of October, one month after the sighting reported here, one of the authors (MR) visited San Fernando Bay again but did not sight whales, but was told by local fishermen that whales were seen leaving San Fernando around the last days of September.

Documentation of $19^{\text {th }}$ century whaling, indicated whaling grounds for right whales off northern Peru between $5^{\circ}-15^{\circ} \mathrm{S}$ and $80^{\circ}-85^{\circ} \mathrm{W}$ (Maury, 1851). If this information was accurate, feeding and/or breeding grounds of southern Right Whales may have existed in Peruvian waters before the beginning of the whaling period (Van Waerebeek et al., 1998). This present sighting may indicate that the end of whaling activity, and the full protection of E. australis are allowing the populations to recover and reclaim ancient breeding grounds in the South Pacific and South Atlantic Oceans (Mermoz, 1980; Aguayo et al., 1992; Canto et al., 1992; Van Waerebeek et al., 1992, 1998; Lodi et al., 1996; Greig et al., 2001; Santos et al., 2001; Patenaude, 2003).

\section{Acknowledgements}

Andres Chipollini and Marco Portal (IMARPE) helped with the digital processing of video images. Dr. Koen Van Waerebeek (CEPEC) provided literature and gave useful suggestions on the manuscript. Also thanks to the comments of Ricardo Bastida and an anonymous reviewer.

\section{References}

Aguayo, A., Cárdenas, J. and Torres, D. (1992) Análisis de los avistamientos de Eubalaena australis (Desmoulins, 1822) en aguas chilenas, desde 1983 hasta 1989. Series. Cientificas. Instituto Nacional Antártico Chileno 42: 77-91.

Canto, J., Ruiz, P. and Yáñez, J. (1992) Registro de nuevas especies de cetáceos para la costa de Chile y antecedentes del grupo. Boletín Museo Nacional de Historia Natural de Chile 43: 105-115.

Greig, A.B., Secchi, E.R., Zerbini, A.N. and Dalla Rosa, L. (2001) Stranding events of southern right whales, Eubalaena australis, in southern Brazil. Journal of Cetacean Research and Management (Special Issue) 2: 157-160.

Lodi, L., Siciliano, S. and Bellini, C. (1996) Ocorrências e conservação de baleias-francas-do-sul, Eubalaena australis, no litoral do Brasil. Papéis Avulsos de Zoologia, São Paulo 39(17): 307-328.

Maury, M.F. (1851) Whale Chart. National Observatory, Bureau of Ordnance and Hydrography, USA.

Mermoz, J.F. (1980) Preliminary Report on the Southern right whale in the South Western Atlantic. Report International Whaling Commission 30: 183-186.

Patenaude, N.J. (2003) Sightings of southern right whales around 'mainland' New Zealand. Science for Conservation 225. 43p.

Santos, M.C., Siciliano, S., Pacheco de Souza, S. And Altmayer, J.L. (2001) Occurrence of southern right whales (Eubalaena australis) along southeastern Brazil. Journal of Cetacean Research and Management. (Special Issue) 2: 153-156.

Van Waerebeek, K., Reyes, J.C. and Van Bressem, M.F. (1998) Sighting of a mother-calf pair of southern right whales Eubalaena australis in Peruvian waters. Estudios Oceanológicos 17: 105-107.

Van Waerebeek, K., Reyes, J.C. and Aranda, C. (1992) Southern right whales (Eubalaena australis) off southern Peru. Marine Mammal Science 8(1): 86-88. 